\title{
Avoidable Burden of Risk Factors for Serious Road Traffic Crashes in Iran: A Modeling Study
}

\author{
Fatemeh Khosravi Shadmani ${ }^{1}$, Kamyar Mansori ${ }^{2,3}$, Manoochehr Karami ${ }^{4}$, Farid Zayeri ${ }^{5}$, Reza Khosravi Shadman ${ }^{6}$, \\ Shiva Mansouri Hanis ${ }^{7}$, Hamid Soori ${ }^{8}$ \\ ${ }^{1}$ Modeling in Health Research Center, Institute for Futures Studies in Health, Kerman University of Medical Sciences, Kerman; ${ }^{2}$ Social Development \\ and Health Promotion Research Center, Gonabad University of Medical Sciences, Gonabad; ${ }^{3}$ Department of Epidemiology, School of Public Health, \\ Iran University of Medical Science, Tehran; ${ }^{4}$ Department of Epidemiology, School of Public Health, Hamadan University of Medical Sciences, \\ Hamadan; ${ }^{5}$ Department of Biostatistics, Faculty of Paramedical, Shahid Beheshti University of Medical Sciences, Tehran; ${ }^{6}$ School of Public Health, \\ Dezful University of Medical Sciences, Dezful; ${ }^{7}$ Social Determinants of Health Research Center, Kurdistan University of Medical Sciences, Sanandaj; \\ ${ }^{8}$ Safety Promotion and Injury Prevention Research Center, Shahid Beheshti University of Medical Sciences, Tehran, Iran
}

Objectives: The aim of this study was to model the avoidable burden of the risk factors of road traffic crashes in Iran and to prioritize interventions to reduce that burden.

Methods: The prevalence and the effect size of the risk factors were obtained from data documented by the traffic police of Iran in 2013. The effect size was estimated using an ordinal regression model. The potential impact fraction index was applied to calculate the avoidable burden in order to prioritize interventions. This index was calculated for theoretical, plausible, and feasible minimum risk level scenarios. The joint effects of the risk factors were then estimated for all the scenarios.

Results: The highest avoidable burdens in the theoretical, plausible, and feasible minimum risk level scenarios for the non-use of child restraints on urban roads were $52.25,28.63$, and 46.67 , respectively. In contrast, the value of this index for speeding was $76.24,37.00$, and 62.23 , respectively, for rural roads.

Conclusions: On the basis of the different scenarios considered in this research, we suggest focusing on future interventions to decrease the prevalence of speeding, the non-use of child restraints, the use of cell phones while driving, and helmet disuse, and the laws related to these items should be considered seriously.

Key words: Traffic accidents, Risk factors, Prevalence, Human, Iran

\section{INTRODUCTION}

Previous studies have shown that the annual incidence rate of traffic crashes is 34.1 per 100000 persons in Iran, whereas

Received: September 12, 2016 Accepted: February 6, 2017

Corresponding author: Hamid Soori, PhD

Parvaneh St., Tehran 1997673783, Iran

Tel/Fax: +98-212-243-2040

E-mail: hsoori@yahoo.com

This is an Open Access article distributed under the terms of the Creative Commons Attribution Non-Commercial License (http://creativecommons.org/licenses/bync/4.0// which permits unrestricted non-commercial use, distribution, and reproduction in any medium, provided the original work is properly cited. this rate is 18.0 per 100000 globally [1]. Furthermore, traffic crashes are known to be the second most common cause of death and the greatest cause of years of potential life lost in Iran [2]. In general, years of life lost due to early deaths related to this phenomenon in Iran are higher than in the Eastern Mediterranean and the rest of the world [3].

The only serious and effective action for controlling traffic crashes is the implementation of preventive interventions. However, if these interventions are not designed properly, they may lead to the waste of available resources. Typically, the population attributable fraction (PAF) is used to persuade health system policymakers to implement an intervention. 
The assumption for calculating the PAF is a decrease in the prevalence of exposure to a specific risk factor to zero [4]. However, complete removal of exposure to a risk factor is impossible at the community level. Although this index is used for prioritizing risk factors, it is not suitable for planning goals. Therefore, policymakers usually want to know what changes in the disease burden or morbidity rate can be expected if the prevalence of a risk factor decreases to the expected level [5]. Therefore, the potential impact fraction (PIF) is calculated; it is defined as a decrease in the fraction of a disease as a result of a change in the present distribution of the risk factors (avoidable burden) [6]. Determining this index is more important for public health, health system policymakers, and the people financing preventive interventions.

The World Health Organization (WHO) has recommended measures for the prevention of road traffic injuries for a number of risk factors, but thus far, no investigation has been conducted on the suitability of these activities and their prioritization in Iran. Therefore, the goal of the present study was to prioritize preventive interventions regarding traffic crashes and to provide necessary information to health system policymakers and decision-makers for nationwide macro-planning; this prioritizing is done on the basis of the avoidable burden of risk factors.

\section{METHODS}

In this research, the data documented in the National Register of Accidents by the police were used. We examined all types of crashes that occurred in Iran in 2012, including those that caused death, injury, or damage. Injury, in this study, refers to any type of physical or mental problem suffered by the driver or the other occupants of a vehicle as a result of an accident, while, according to the police department, non-injury crashes are those involving a damaged vehicle but no injury to the occupants. The risk factors investigated in this study were those for which the WHO has suggested certain main preventive strategies. For calculating PIF, the factual prevalence of exposure to the risk factor, the effect size of the risk factor, and the counterfactual prevalence of exposure to the risk factor (hypothetical prevalence) are required. The factual prevalence of exposure to the risk factor and the effect size were obtained from the registered data. The adjusted effect size was obtained by using an ordinal regression model in the form of the adjusted odds ratio (OR) for confounding factors. In this model, the dependent variable was severe traffic crashes (those that caused death or injury). The category of non-injury crashes was considered the reference. Since the data documented by the police system did not contain the risk factors of cell phone use while driving and non-use of child restraints, the prevalence of these two risk factors was obtained from other studies conducted in Iran $[7,8]$. The effect size of cell phone use while driving and non-use of child restraints was estimated using other studies in terms of the OR and the relative risk, respectively $[9,10]$. The chi-square test revealed no statistically significant difference among different age groups with respect to the prevalence of exposure to the risk factors. Therefore, prevalence was not calculated according to age groups. It was calculated according to sex and urban vs. rural types of roads. Counterfactual prevalence was determined for three levels: the theoretical minimum risk level, the plausible minimum risk level, and the feasible minimum risk level.

\section{Theoretical Minimum Risk Level (Scenario 1)}

This level for all risk factors (drunk driving, drug abuse by the driver, driver fatigue and drowsiness, non-use of driver-side seat belts, non-use of motorcycle helmets, cell phone use while driving, non-use of child restraints, insufficient road lighting, road defects, and vehicle defects) was considered to be zero.

\section{Plausible Minimum Risk Level (Scenario 2)}

This level was defined as the level of potential prevalence decrease for risk factors in Iranian society. This level was determined by experts and by using the Delphi method. First, some questions were posed by the researchers regarding the plausible minimum risk level; then, a group of experts, consisting of a policymaker, an epidemiologist, a traffic crash specialist (from the Law Enforcement Force of Islamic Republic of Iran), and a physician working in the trauma section, was requested to state its comments and start discussing them. After reaching a conclusion, the plausible minimum risk level for each factor was determined. Finally, the researchers determined the level of prevalence decrease for the risk factors after considering the views of all the experts.

\section{Feasible Minimum Risk Level (Scenario 3)}

This is the level of exposure decrease that other communities have achieved. The risk factors were identified by a comprehensive review of the existing literature [11], and the lowest level for these factors was chosen. This level was determined by the experts for some other risk factors for which no 
related studies were found.

Then, the avoidable burden of traffic crashes when a preventive intervention was provided in the abovementioned scenarios was calculated using equation 1 .

$$
P I F=\frac{\sum_{i=1}^{n} P_{i} R R_{i}-\sum_{i=1}^{n} P_{i}^{\prime} R R_{i}}{\sum_{i=1}^{n} P_{i} R R_{i}}
$$

Here, $R R$ represents a general term related to one of the measurement indices of association (effect), namely relative risk, rate ratio, $\mathrm{OR}$, and hazard ratio. $P, P^{\prime}$, and $\mathrm{n}$ represent the factual prevalence of exposure to the risk factor, counterfactual prevalence (hypothetical), and high level of exposure, respectively.

\section{Joint Effect of Risk Factors}

Equation 2 was used for estimating the joint effect of avoidable burden as a result of a simultaneous prevalence decrease in the considered risk factors.

$$
P I F=1-\prod_{i=1}^{n}\left(1-P I F_{i}\right)
$$

\section{Sensitivity Analysis}

Given the uncertainty of prevalence, random errors, and the obtained estimates, in addition to calculating the PIF for estimating the point prevalence, we calculated the $95 \%$ confidence interval (CI) for the PIF. For this purpose, @Risk version 6 (Palisade Co., Ithaca, NY, USA) was used along with a uniform distribution, 2000 iterations, and the Monte Carlo simulation method. Then, values between $2.5 \%$ and $97.5 \%$ were reported as the estimate of the $95 \%$ uncertainty.

\section{RESULTS}

Table 1 presents the characteristics of the drivers involved in all the crashes. As can be seen, in the case of urban roads, the mean age of males and females was $33.57 \pm 11.79$ years and
$32.42 \pm 8.98$ years, respectively, and for rural roads, it was 35.16 \pm 11.42 years and $32.06 \pm 8.23$, respectively. Table 2 presents the exposure prevalence for different risk factors (real and counterfactual). The highest factual prevalence was of the non-use of motorcycle helmets on urban roads (47.50\%; $95 \%$ $\mathrm{Cl}, 46.96$ to $48.05 \%)$ and on rural roads $(51.70 \% ; 95 \% \mathrm{Cl}, 51.14$ to $52.25 \%)$. Further, the counterfactual prevalence for this risk factor was the highest at the plausible minimum risk level. Table 3 presents the effect size and $95 \% \mathrm{Cl}$ according to urban and rural roads and sex. In this analysis, the largest measure of effect was related to the risk factor of speeding, with values of $5.75 \%(95 \% \mathrm{Cl}, 4.34$ to $7.61 \%)$ and $5.00 \%(95 \% \mathrm{Cl}, 4.71$ to $5.25 \%)$ for females and males, respectively. These numbers for rural roads were $14.87 \%(95 \% \mathrm{Cl}, 10.91$ to $18.54 \%)$ and $12.8 \%$ $(95 \% \mathrm{Cl}, 12.06$ to $13.59 \%)$, respectively.

The counterfactual prevalence in every scenario and the calculated PIF according to urban and rural roads are presented in Table 4. The maximum PIF for death and injury was attributed to the non-use of safety belts on rural roads; here, the PIF for the theoretical, plausible, and feasible levels was 52.25 (95\% Cl, 47.28 to 57.21$), 28.63$ ( $95 \% \mathrm{Cl}, 25.89$ to 69.11 ), and 46.67 ( $95 \% \mathrm{Cl}, 43.14$ to 52.20 ), respectively. The lowest PIF for the theoretical, plausible, and feasible minimum risk levels in males was found for drunk driving, with values of 0.28 (95\% $\mathrm{Cl}, 0.25$ to 0.30$), 0.14(95 \% \mathrm{Cl}, 0.12$ to 0.15$)$, and $0.28(95 \% \mathrm{Cl}$, 0.25 to 0.30 ), respectively. These rates for females were 0.25 ( $95 \% \mathrm{Cl}, 0.22$ to 0.27$), 0.13(95 \% \mathrm{Cl}, 0.11$ to 0.14 ), and 0.25 $(95 \% \mathrm{Cl}, 0.22$ to 0.27$)$, respectively. The maximum PIF for rural roads was related to unauthorized speed (Table 4). If this values decreases to the level shown in the Table 4, it will be possible to more effectively prevent the burden of traffic crashes. The joint effect of exposure to the studied risk factors related to traffic crashes is shown in Figure 1 according to sex. The joint effect of the risk factors for both sexes was higher in the case of rural roads than in the case of urban roads.

Table 1. Characteristics of drivers in all crashes

\begin{tabular}{llrlrrr}
\hline \multirow{2}{*}{ Road type } & Sex & Frequency & Age & \multicolumn{3}{c}{ Outcome } \\
\cline { 5 - 7 } & & & & Death & \multicolumn{1}{c}{ Injury } & No injury \\
\hline Urban & Male & 147178 & $33.57 \pm 11.79$ & $1282(0.9)$ & $84678(57.5)$ & $61218(41.6)$ \\
& Female & 11586 & $32.42 \pm 8.98$ & $32(0.3)$ & $5889(51.7)$ & $5565(48.0)$ \\
Rural & Male & 68879 & $35.16 \pm 11.42$ & $4043(5.9)$ & $28189(40.9)$ & $36647(53.2)$ \\
& Female & 2177 & $32.06 \pm 8.23$ & $112(5.1)$ & $836(38.4)$ & $1229(56.5)$ \\
Total & & 229820 & $33.97 \pm 11.56$ & $5469(2.4)$ & $119692(52.1)$ & $104659(45.5)$ \\
\hline
\end{tabular}

Values are presented as mean \pm standard deviation or frequency (\%). 
Table 2. Prevalence (real and counterfactual) of the risk factors

\begin{tabular}{|c|c|c|c|c|c|c|c|c|c|}
\hline \multirow{3}{*}{ Risk factors } & & \multicolumn{2}{|c|}{ Factual prevalence } & \multicolumn{6}{|c|}{ Counterfactual prevalence } \\
\hline & & \multirow{2}{*}{$\begin{array}{l}\text { Urban } \\
\text { roads }\end{array}$} & \multirow{2}{*}{$\begin{array}{l}\text { Rural } \\
\text { roads }\end{array}$} & \multicolumn{3}{|c|}{ Urban } & \multicolumn{3}{|c|}{ Rural } \\
\hline & & & & $\begin{array}{c}\text { Scenario } \\
1\end{array}$ & $\begin{array}{c}\text { Scenario } \\
2\end{array}$ & $\begin{array}{c}\text { Scenario } \\
3\end{array}$ & $\begin{array}{c}\text { Scenario } \\
1\end{array}$ & $\begin{array}{c}\text { Scenario } \\
2\end{array}$ & $\begin{array}{c}\text { Scenario } \\
3\end{array}$ \\
\hline \multirow[t]{2}{*}{ Unauthorized speed } & Male & $19.70(19.53,19.68)$ & $27.2(27.01,27.38)$ & 0.00 & 10.00 & 5.00 & 0.00 & 14.00 & 5.00 \\
\hline & Female & $16.20(16.04,16.35)$ & $20.6(20.43,20.76)$ & 0.00 & 8.00 & 5.00 & 0.00 & 10.00 & 5.00 \\
\hline \multirow[t]{2}{*}{ Drug abuse } & Male & $2.40(2.33,2.46)$ & $3.00(2.96,3.03)$ & 0.00 & 1.20 & 0.02 & 0.00 & 1.50 & 0.02 \\
\hline & Female & $1.40(1.35,1.44)$ & $1.40(1.35,1.44)$ & 0.00 & 0.70 & 0.02 & 0.00 & 0.70 & 0.02 \\
\hline \multirow[t]{2}{*}{ Driver fatigue and drowsiness } & Male & $4.20(4.11,4.28)$ & $13.50(13.36,13.63)$ & 0.00 & 0.50 & 1.00 & 0.00 & 7.80 & 1.00 \\
\hline & Female & $3.50(3.42,3.57)$ & $12.90(12.76,13.03)$ & 0.00 & 1.75 & 1.00 & 0.00 & 6.50 & 1.00 \\
\hline Non-use of driver-side seat belts & Male & $30.00(29.79,30.20)$ & $40.60(40.38,40.81)$ & 0.00 & 15.00 & 4.00 & 0.00 & 20.30 & 4.00 \\
\hline Road defects & & $10.30(10.17,10.42)$ & $22.30(22.12,22.47)$ & 0.00 & 36.00 & 13.30 & 0.00 & 36.00 & 13.30 \\
\hline Vehicle defects & & $4.70(4.61,4.78)$ & $6.30(6.20,6.39)$ & 0.00 & 14.70 & 2.00 & 0.00 & 15.70 & 2.00 \\
\hline \multicolumn{10}{|l|}{ Cell phone use while driving } \\
\hline Other studies & & \multicolumn{2}{|c|}{$30.00(29.81,30.18)$} & 0.00 & 5.10 & 3.00 & & 11.10 & 2.00 \\
\hline \multicolumn{10}{|l|}{ Non-use of child restraints } \\
\hline Other studies & & \multicolumn{2}{|c|}{$72.00(68.89,75.11)$} & 0.00 & 2.30 & 3.00 & 0.00 & 3.10 & 3.00 \\
\hline
\end{tabular}

Values are presented prevalence (95\% confidence interval).

Table 3. The effects of risk factors

\begin{tabular}{|c|c|c|c|c|c|}
\hline \multirow{2}{*}{ Risk factor } & \multirow{2}{*}{ Category } & \multicolumn{2}{|c|}{ Urban roads } & \multicolumn{2}{|c|}{ Rural roads } \\
\hline & & Male & Female & Male & Female \\
\hline Speeding (ref: legal) & Illegal & $5.00(4.71,5.25)$ & $5.75(4.34,7.61)$ & $12.8(12.06,13.59)$ & $14.87(10.91,18.54)$ \\
\hline Drunk driving (ref: no) & Yes & $1.15(1.13,1.167)$ & $1.21(1.08,1.36)$ & $1.69(1.36,1.84)$ & $2.09(1.91,2.28)$ \\
\hline Drug abuse (ref: no) & Yes & $1.57(1.45,1.69)$ & $1.37(1.05-1.77)$ & $1.72(1.55,1.91)$ & $2.96(1.63,5.37)$ \\
\hline Driver fatigue and drowsiness (ref: no) & Yes & $1.37(1.29,1.46)$ & $1.30(1.05,1.62)$ & $2.03(1.69,2.42)$ & $1.92(1.65,2.23)$ \\
\hline Non-use of driver-side seat belts (ref: no) & Yes & $1.47(1.22,1.79)$ & $1.67(1.61,1.91)$ & $1.97(1.89,2.28)$ & $1.85(1.86,2.05)$ \\
\hline Non-use of motorcycle helmets (ref: yes) & No & $1.55(1.48,1.74)$ & N/A & $1.96(1.70,2.27)$ & $\mathrm{N} / \mathrm{A}$ \\
\hline Insufficient road lighting (ref: light) & Dark & \multicolumn{2}{|c|}{$1.20(1.12,1.29)$} & \multicolumn{2}{|c|}{$1.46(1.30,1.63)$} \\
\hline Road defects (ref: no) & Yes & \multicolumn{2}{|c|}{$1.47(1.23,1.57)$} & \multicolumn{2}{|c|}{$1.96(1.70,2.25)$} \\
\hline Vehicle defects (ref: no) & Yes & \multicolumn{2}{|c|}{$1.24(1.08,1.57)$} & \multicolumn{2}{|c|}{$1.40(1.25,1.57)$} \\
\hline
\end{tabular}

Values are presented as adjusted odds ratio (95\% confidence interval).

$\mathrm{N} / \mathrm{A}$, not applicable.

\section{DISCUSSION}

The maximum PIF for urban areas was found for the following items (in descending order): non-use of child restraints, cell phone use while driving, unauthorized speed, non-use of motorcycle helmets, and non-use of driver-side seat belts. The maximum PIF for rural areas was as follows (in descending order): unauthorized speed, non-use of child restraints, cell phone use while driving, non-use of motorcycle helmets, and non-use of driver-side seat belts. If it is possible to decrease the prevalence of the non-use of child restraints to zero or to the levels evaluated in this study, that will correspond to the maximum avoidable burden in urban areas. Although the non-use of child restraints had lower OR than the other factors, because of its higher prevalence, it was found to have a higher priority. Because both the prevalence and the effect 
Table 4. Potential impact fraction (PIF) on urban and rural roads

\begin{tabular}{|c|c|c|c|c|c|c|c|}
\hline \multirow{2}{*}{ Risk factors } & \multirow{2}{*}{ Sex } & \multicolumn{3}{|c|}{ PIF on urban roads $(\%)$} & \multicolumn{3}{|c|}{ PIF on rural roads $(\%)$} \\
\hline & & Scenario 1 & Scenario 2 & Scenario 3 & Scenario 1 & Scenario 2 & Scenario 3 \\
\hline \multirow[t]{2}{*}{ Speeding } & Male & $44.07(39.88,48.25)$ & $21.70(20.71,25.90)$ & $32.89(29.77,36.01)$ & $76.24(68.99,83.48)$ & $37.00(33.48,40.51)$ & $62.23(56.31,68.14)$ \\
\hline & Female & $43.49(39.36,47.62)$ & $22.01(19.91,24.09)$ & $30.06(27.20,32.91)$ & $48.21(43.63-52.79)$ & $38.20(34.50,41.74)$ & $56.00(5.68,61.32)$ \\
\hline \multirow[t]{2}{*}{ Drunk driving } & Male & $0.28(0.25,0.30)$ & $0.14(0.12,0.15)$ & $0.28(0.25,0.30)$ & $1.36(1.23,1.48)$ & $0.68(0.61,0.74)$ & $1.35(1.22,1.47)$ \\
\hline & Female & $0.25(0.22,0.27)$ & $0.13(0.11,0.14)$ & $0.25(0.22,0.27)$ & $0.86(0.77-0.94)$ & $0.43(0.38,0.47)$ & $0.85(0.76,0.93)$ \\
\hline \multirow[t]{2}{*}{ Drug abuse } & Male & $1.35(1.22,1.47)$ & $0.67(0.60,0.73)$ & $1.43(1.21,1.46)$ & $2.11(1.90,2.31)$ & $1.06(1.21,1.46)$ & $2.10(2.08,2.89)$ \\
\hline & Female & $0.52(0.47,0.56)$ & $0.26(0.23,0.28)$ & $0.51(0.46,0.55)$ & $2.67(2.21,2.92)$ & $1.34(1.21,1.46)$ & $2.64(2.38,2.89)$ \\
\hline \multirow{2}{*}{$\begin{array}{l}\text { Driver fatigue and } \\
\text { drowsiness }\end{array}$} & Male & $1.53(1.38,1.67)$ & $0.77(0.69,0.84)$ & $1.17(1.05,1.28)$ & $12.21(11.05,13.37)$ & $5.15(4.68,5.61)$ & $11.30(10.22,12.33)$ \\
\hline & Female & $1.04(0.94,1.13)$ & $0.52(0.69,0.84)$ & $0.74(0.66,0.81)$ & $10.61(9.60,11.61)$ & $5.26(4.70,5.75)$ & $9.79(8.59,10.71)$ \\
\hline \multirow{2}{*}{$\begin{array}{l}\text { Non-use of driver- } \\
\text { side seat belts }\end{array}$} & Male & $12.36(11.18,13.55)$ & $6.18(5.59,6.76)$ & $10.71(9.69,11.72)$ & $28.25(25.57,30.93)$ & $14.13(12.78,15.47)$ & $25.47(23.05,27.89)$ \\
\hline & Female & $15.37(13.91,16.83)$ & $7.71(6.97,8.44)$ & $13.10(11.85,14.34)$ & $24.12(21.82,26.41)$ & $12.06(10.91,13.20)$ & $21.54(19.49,23.58)$ \\
\hline $\begin{array}{l}\text { Non-use of motor- } \\
\text { cycle helmets }\end{array}$ & Male & $20.71(18.74,22.67)$ & $16.49(14.92,18.05)$ & $18.97(17.16,20.77)$ & $33.17(30.02,36.32)$ & $10.25(9.27,11.22)$ & $33.17(30.02,26.32)$ \\
\hline $\begin{array}{l}\text { Cell phone use } \\
\text { while driving }\end{array}$ & & $48.19(43.61,52.77)$ & $24.09(21.80,26.37)$ & $36.94(33.43,40.45)$ & $48.19(43.61,52.77)$ & $24.09(21.80,26.37)$ & $36.94(33.43,40.45)$ \\
\hline $\begin{array}{l}\text { Non-use of child } \\
\text { restraints }\end{array}$ & & $52.25(47.28,57.21)$ & $28.63(25.89,36.91)$ & $46.67(43.14,52.20)$ & $52.25(47.28,57.21)$ & $28.63(25.89,36.95)$ & $46.76(43.14,52.20)$ \\
\hline $\begin{array}{l}\text { Insufficient road } \\
\text { lighting }\end{array}$ & & $6.37(5.76,6.90)$ & $3.21(2.90,3.51)$ & $5.94(5.37,6.50)$ & $21.12(19.11,23.12)$ & $10.59(9.85,1.59)$ & $19.78(17.89,21.56)$ \\
\hline Road defects & & $7.61(6.88,8.33)$ & $3.75(3.93,4.10)$ & $5.40(4.48,5.91)$ & $19.26(17.42,21.08)$ & $9.68(8.76,10.59)$ & $16.67(15.08,18.25)$ \\
\hline Vehicle defects & & $3.71(3.35,4.06)$ & $1.89(1.71,2.06)$ & $1.34(1.21,1.46)$ & $8.00(7.23,8.76)$ & $4.06(3.67,4.44)$ & $4.19(3.79,4.58)$ \\
\hline
\end{tabular}

Values are presented as PIF (95\% confidence interval).

Avoidable burden of the risk factors

(\%)

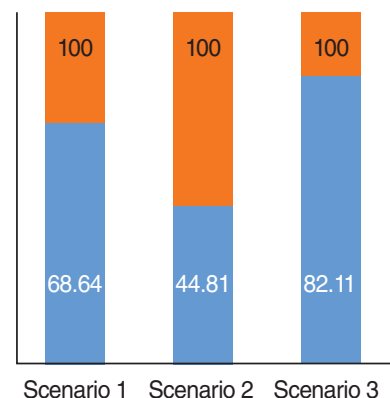

Urban roads

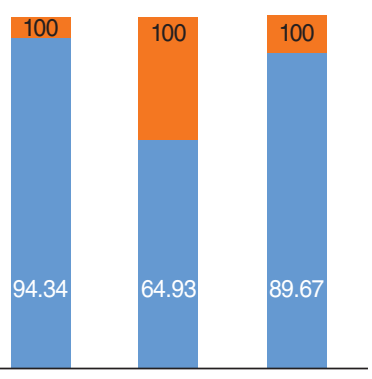

Scenario 1 Scenario 2 Scenario 3 Rural roads
Burden of road traffic injuries

(\%)

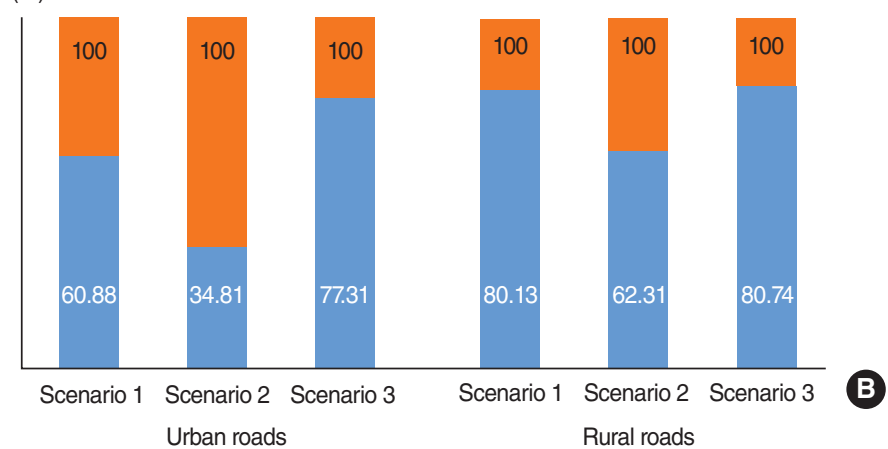

Figure 1. Joint effect of all risk factors (A) males and (B) females.

size of a risk factor are used for calculating the PIF, the removal of or decrease in exposure to high severity and an average increase in the risk level have the same (or less) effect nationwide as the removal of a rare risk factor that poses a considerably greater risk of disease [12].

It was estimated in a study conducted in the US that $22 \%$ of the burden due to traffic crashes can be avoided by preventing cell phone use while driving [13]. While this rate was $7 \%$ on average in that study, it was estimated to be $30 \%$ in Iran. The second priority in urban areas is unauthorized speed. It is possible to lose control of a vehicle when driving it at a high speed; the driver's reaction time is also slow in such a case. Therefore, there is a possibility of severe traffic crashes. In fact, a $5 \%$ increase in the average speed has been shown to lead to 10 and $20 \%$ increases in injuries and deaths, respectively [14]. In rural areas, the prevalence and the OR of unauthorized speed are greater than in urban areas, and hence, this risk factor has the highest priority in rural areas. The second and the third highest priorities in these areas are the non-use of child restraints and cell phone use while driving. Recently, because 
of the introduction of a strict seat-belt use law and the success of the police in enforcing it, the prevalence of the latter risk factor has decreased; however, it is still a priority. Although the motorcycle helmet use law is obligatory, it is not followed seriously, and the prevalence of the related risk factor is so high that its priority is higher than that of seat belt use.

The other studied risk factors included drunk driving and drug abuse. It is estimated that $53 \%$ of the deaths caused by traffic crashes in the US are associated with drunk driving [15]. However, this factor is less important because of its low prevalence in Iran. This may be attributed to the following two reasons: First, an alcohol detection test is not given to all drivers involved in accidents; only if the police are suspicious of a driver is the alcohol test administered. Second, police reports of a driver's consumption of alcohol in connection with accidents are insufficient. However, the prevalence of alcohol and drug abuse among Iranian drivers is low, and taking measures against such abuse is not a top priority. Although driver fatigue and drowsiness while driving is not considered important in urban areas, it is rather important in rural areas. Different studies have found various values of the burden of traffic crashes caused by this factor. These values have been reported to be $13 \%$ [15], 33\% [16], and 10\% [17], in the US, Australia, and France, respectively; the difference in these values is associated with the prevalence difference in various countries. In general, the most avoidable burdens are those that are due to human factors. Insufficient road lighting was the most important environmental factor. Its importance can be attributed to driving at night, which is usually accompanied by fatigue and drowsiness; these factors together increase the possibility of accidents.

For some risk factors such as the non-use of motorcycle helmets, the PIF for the theoretical minimum risk level is equal to that of the plausible minimum risk level. This indicates that the prevalence can be decreased to zero, as some other communities have been able achieve this. It also shows that preventive measures have been effective. Therefore, investigations on methods of decreasing the prevalence of risk factors should be conducted according to their priority. Moreover, some present measures must be developed further and followed seriously. Interpreting the effects of the decreased prevalence of a risk factor on the death and injury rate is difficult because these changes may have been brought about by factors other than the considered risk factors and/or by a combination of several risk factors that become involved simultaneously. The joint effect of the considered risk factors, which is close to $100 \%$, showed that these factors were more important in rural areas than in urban areas. In other words, in the absence of the risk factors examined in this study, the risk of traffic crashes is very low. The joint effect of the risk factors is less than $100 \%$ in urban areas; this could be attributed to the presence of other risk factors in these areas. The theoretical minimum risk level is similar to the PAF and can be used as a guide for conducting further research on these risk factors and developing the resources to do so. The exposure distribution for the theoretical minimum risk level may depend on the sex and age variables, but in general, it is independent of the geographical area. The plausible and feasible minimum risk levels differ in various populations according to the present distribution of the disease burden, accessible resources, and facilities for exposure decrease [18].

One of the strengths of this study is the large volume of data and the use of data obtained at the national level. Moreover, the effects of the considered risk factors were obtained from a nationwide source that was adjusted for confounders. The prevalence of risk factors according to sex and urban and rural areas was used on the basis of the updated data. However, this study had some limitations. The Iranian police use the KAM114 form to document all crashes. They gather information for all five fields. Some of the values are provided by occupants and obviously, might be subject to underestimation. In other words, information regarding age, sex, education, occupation, and confunding factors in the five fields is recorded in the KAM114 form by the police, and there are no limitations in this regard. However, there were some missing factors in the variables, which were estimated using multiple imputation. Registered deaths were those in the database that occurred at the crash site. They do not include deaths that occurred in hospitals and/or 30 days after the accidents. This is because other databases do not contain any data about risk factors and thus, could not be linked to the database that we used. The data regarding the risk factors of cell phone use while driving and non-use of child restraints were not registered by the police, and their effect size used in the PIF and PAF calculations is based on other studies, as was their prevalence value.

The priorities that we determined for implementing preventive strategies in urban areas are as follows: use of child restraints, no use of cell phones while driving, speed management, use of motorcycle helmets, use of driver-side seat belts, lack of road defects, better road lighting, prevention of driver 
fatigue and drowsiness, no use of drugs, and no use of alcohol. Further, the priorities that were identified for rural areas are as follows: speed management, use of safety belts, no use of cell phones while driving, use of motorcycle helmets, prevention of driver fatigue and drowsiness, better road lighting, lack of road defects, lack of vehicle defects, no use of drugs, and no use of alcohol.

\section{ACKNOWLEDGEMENTS}

We would like to express our sincere gratitude to the traffic police of Iran(NAJA) for providing data for this study and for cooperating with us in this study.

\section{CONFLICT OF INTEREST}

The authors have no conflicts of interest associated with the material presented in this paper.

\section{ORCID}

Fatemeh Khosravi Shadmani http://orcid.org/0000-00025172-7950

Kamyar Mansori http://orcid.org/0000-0001-5008-8547

Manoochehr Karami http://orcid.org/0000-0002-9026-3757

Farid Zayeri $h t t p: / / o r c i d . o r g / 0000-0002-7791-8122$

Reza Khosravi Shadman http://orcid.org/0000-0003-05794586

Shiva Mansouri Hanis http://orcid.org/0000-0001-7107-4996

Hamid Soori http://orcid.org/0000-0002-3775-1831

\section{REFERENCES}

1. World Health Organization. Global status report on road safety 2013 [cited 2013 Mar 6]. Available from: http://www.who.int/ violence_injury_prevention/road_safety_status/2013/en/.

2. Soori H, Hatam Abadi HR, Vafaei R, Hadadi M, Ayni E, Asna Ashari HR. Pattern epidemiologic road traffic injuries Tehran-Abali road: a cohort study. Payesh 2010;11(11): 29-37 (Persian).

3. Khorasani-Zavareh D, Mohammadi R, Khankeh HR, Laflamme L, Bikmoradi A, Haglund BJ. The requirements and challenges in preventing of road traffic injury in Iran. A qualitative study. BMC Public Health 2009;9:486.

4. Rockhill B, Newman B, Weinberg C. Use and misuse of population attributable fractions. Am J Public Health 1998;88(1):15-
19.

5. Karami M, Soori H, Monfared AB. Estimating the contribution of selected risk factors in attributable burden to stroke in Iran. Iran J Public Health 2012;41(5):91-96.

6. Murray CJ, Lopez AD. On the comparable quantification of health risks: lessons from the Global Burden of Disease Study. Epidemiology 1999;10(5):594-605.

7. Hajihosseinlo M, Abolhasani M, Emadi A. Effects of cell phone use during the driving and its role in the occurrence of road traffic accidents; 2008 [cited 2017 Mar 15]. Available from: https://www.civilica.com/Paper-TTC08-TTC08_092.html (Persian).

8. Ayni E. Opportunities and threats to mandatory law of child restraint usage in Iran. J Saf Promot Inj Prev 2013;1(1):37-43 (Persian).

9. McEvoy SP, Stevenson MR, McCartt AT, Woodward M, Haworth C, Palamara P, et al. Role of mobile phones in motor vehicle crashes resulting in hospital attendance: a case-crossover study. BMJ 2005;331(7514):428.

10. Cummings P, Rivara FP, Olson CM, Smith KM. Changes in traffic crash mortality rates attributed to use of alcohol, or lack of a seat belt, air bag, motorcycle helmet, or bicycle helmet, United States, 1982-2001. Inj Prev 2006;12(3):148-154.

11. Soori H, Ebn Ahmadi A, Ashrafi Hafez A, Hatam Abadi HR, Hadadi $M$, Ayni E. Speed management: a road safety manual for decicion-makers and practitioners. Tehran: Research Center of NAJA; 2009, p. 75 (Persian).

12. Eide GE. Attributable fractions for partitioning risk and evaluating disease prevention: a practical guide. Clin Respir J 2008; 2 Suppl 1:92-103.

13. Farmer CM, Braitman KA, Lund AK. Cell phone use while driving and attributable crash risk. Traffic Inj Prev 2010;11(5):466470.

14. World Health Organization. Speed management: a road safety manual for decision-makers and practitioners; 2008 [cited 2017 Feb 28]. Available from: http://apps.who.int/iris/bitstre am/10665/43915/1/9782940395040_eng.pdf.

15. Lyznicki JM, Doege TC, Davis RM, Williams MA. Sleepiness, driving, and motor vehicle crashes. Council on Scientific Affairs, American Medical Association. JAMA 1998;279(23):19081913.

16. Philip P, Vervialle F, Le Breton P, Taillard J, Horne JA. Fatigue, alcohol, and serious road crashes in France: factorial study of national data. BMJ 2001;322(7290):829-830.

17. Pierce RJ. Driver sleepiness: occupational screening and the 
physician's role. Aust N Z J Med 1999;29(5):658-661.

18. World Health Organization. Comparative quantification of health risks: global and regional burden of disease attribution to selected major risk factors [cited 2012 Jul 6]. Available from: http://www.who.int/healthinfo/global_burden_disease/cra/ en/. 